Page $349-368$

\title{
Biaya Promosi dan Penghimpunan Dana Pihak Ketiga Pada Bank Pembiayaan Rakyat Syariah
}

\author{
Fachrunnisa \\ Universitas Muhammadiyah Prof. Dr. Hamka \\ runyfachrunnisa26@gmail.com
}

\begin{abstract}
The aim of this study is to analyze whether there is influence the expense of promotion is issued to against amount of third party assembled by BPRS. In addition, to analyze the variable lag time (lag) cost of promotion that the most effective effect on changes in third party funds obtained by BPRS. This study used regression analysis or AutoRegressive Distributed Lag (ARDL). The variables used are promotion cost as independent variable and third party fund as dependent variable. The result of this study showed that the amount of promotion cost has a positive and significant influence on the increasing amount of third party funds of BPRS, as explained by the results of ARDL analysis conducted by the author, that is change in third party funds affected by third party funds one quarter earlier and influenced by the amount of promotional costs the previous quarter or 15 months earlier. This indicates that the higher the promotion expense of budget, the BPRS will be able to collect more third party funds.
\end{abstract}

Key Words: the promotion cost, deposit funds, Islamic rural banking

\begin{abstract}
Abstrak
Tujuan dari penelitian ini adalah untuk menganalisis apakah terdapat pengaruh biaya promosi yang dikeluarkan terhadap perubahan jumlah dana pihak ketiga yang dihimpun BPRS dan untuk menganalisis variabel jeda waktu (lag) biaya promosi yang paling efektif pengaruhnya terhadap perubahan dana pihak ketiga yang diperoleh BPRS. Penelitian ini menggunakan analisis regresi AutoRegressive Distributed Lag (ARDL). Variabel yang digunakan adalah biaya promosi sebagai variabel independen dan dana pihak ketiga sebagai variabel dependen. Hasil penelitian menunjukkan bahwa besaran biaya promosi memiliki pengaruh positif dan signifikan terhadap meningkatnya jumlah dana pihak ketiga BPRS, sebagaimana dijelaskan oleh hasil analisis ARDL yang dilakukan penulis, yaitu perubahan dana pihak ketiga dipengaruhi oleh dana pihak ketiga satu triwulan sebelumnya dan dipengaruhi oleh besaran biaya promosi lima triwulan sebelumnya atau 15 bulan sebelumnya. Hal ini menandakan bahwa semakin tinggi anggaran biaya promosi yang dilakukan, maka BPRS akan mampu menghimpun dana pihak ketiga lebih besar.
\end{abstract}

Kata Kunci: biaya promosi, dana pihak ketiga, bank pembiayaan rakyat syariah.

Diterima: 10 Juli 2017; Revisi: 30 Agustus 2017; Disetujui: 10 September 2017 


\section{PENDAHULUAN}

Pada era globalisasi saat ini, lembaga keuangan berkembang sangat pesat, baik di negara sendiri maupun di mancanegara. Perbankan merupakan salah satu lembaga keuangan yang berkembang di Indonesia. Keberadaan bank sangat mempengaruhi pertumbuhan suatu negara karena peranan perbankan tersebut membantu meningkatkan daya beli masyarakat, menciptakan lapangan kerja dan meningkatkan produktivitas kerja. Begitupula dengan perbankan syariah yang mampu memberikan dampak positif terhadap masyarakat. Perkembangan Lembaga Keuangan Syariah secara informal telah dimulai sebelum dikeluarkannya kerangka hukum formal sebagai landasan operasional perbankan syariah di Indonesia. Sebelum tahun 1992 telah didirikan beberapa lembaga keuangan non bank yang telah menerapkan sistem bagi hasil dalam kegiatan operasionalnya. Di Indonesia, regulasi mengenai bank syariah tertuang dalam Undang-Undang No. 21 tahun 2008 tentang perbankan syariah. Bank Syariah adalah bank yang menjalankan kegiatan usahanya berdasarkan prinsip syariah dan menurut jenisnya terdiri dari Bank Umum Syariah, Unit-Unit Syariah dan Bank Pembiayaan Rakyat Syariah (Soemitra, 2010).

Dalam website republika menyatakan periode tahun 2014-2016 adalah tahun yang berat bagi industri perbankan Indonesia. Kondisi ini juga dihadapi perbankan syariah, dalam periode tiga tahun terakhir, rerata pertumbuhan bank syariah turun dari $43.43 \%$ periode $(2009-2012)$ ke $14.96 \%$ periode (20I2-20I5). Bahkan pertumbuhan di tahun 20I4-20I5 sebesar 8.75\% lebih rendah dibandingkan pertumbuhan bank umum nasional yang mencapat 9.21\%. Adapun Laporan Perkembangan Perbankan dan Keuangan Syariah (LPPKS) 2015 dalam berita yang disajikan oleh Otoritas Jasa Keuangan $(\mathrm{O} K \mathrm{~K})$ dalam websitenya menyatakan, seiring dengan kondisi perbankan nasional yang mengalami perlambatan, perkembangan perbankan syariah pada tahun 2015 juga cenderung melambat. Walaupun masih mencatatkan angka positif, pertumbuhan perbankan syariah tahun 2015 tidak lagi setinggi pertumbuhan pada tahun-tahun sebelumnya yang mencapai angka dua digit yang relatif tinggi (bahkan lebih tinggi dibanding perbankan konvensional). Pertumbuhan aset, pinjaman yang diberikan (PYD) dan dana pihak ketiga (DPK) industri perbankan syariah nasional tahun 2015 yang terdiri dari Bank Umum Syariah (BUS), Unit Usaha Syariah (UUS) dan Bank Pembiayaan Rakyat Syariah (BPRS) 
masing-masing mengalami pertumbuhan sebesar 9.00\%, 7.06\% dan 6.37\%, Sebagaimana digambarkan pada Tabel I.

Tabel I. Indikator Perbankan Syariah

\begin{tabular}{|c|c|c|c|c|c|c|}
\hline \multirow[t]{2}{*}{ Indikator } & \multicolumn{6}{|c|}{ Tahun } \\
\hline & 2011 & 2012 & 2013 & 2014 & 2015 & 2016 \\
\hline $\begin{array}{l}\text { Total aset BUS-UUS- } \\
\text { BPRS } \\
\text { (Rp Triliun) }\end{array}$ & 148,99 & $|99,7|$ & $248, I I$ & 278,90 & 304,00 & 356,50 \\
\hline $\begin{array}{l}\text { Pertumbuhan aset BUS- } \\
\text { UUS-BPRS (yoy) }\end{array}$ & - & $34.04 \%$ & $24.24 \%$ & $12.41 \%$ & $9.00 \%$ & $20.33 \%$ \\
\hline Market share & $3.98 \%$ & $4.58 \%$ & $4.89 \%$ & $4.85 \%$ & $4.83 \%$ & $5.12 \%$ \\
\hline $\begin{array}{l}\text { DPK BUS-UUS- BPRS } \\
\text { (Rp Triliun) }\end{array}$ & 117,505 & 150,447 & 187,196 & 221,890 & 236,020 & 297,33 \\
\hline $\begin{array}{l}\text { Pertumbuhan DPK } \\
\text { BUS-UUS-BPRS (yоy) }\end{array}$ & - & $28.03 \%$ & $24.43 \%$ & $18.53 \%$ & $6.37 \%$ & $20.83 \%$ \\
\hline $\begin{array}{l}\text { PYD BUS-UUS- BPRS } \\
\text { (Rp Triliun) }\end{array}$ & 105,335 & 151,063 & 188,553 & 204,310 & 218,725 & 249,09 \\
\hline $\begin{array}{l}\text { Pertumbuhan PYD } \\
\text { BUS-UUS-BPRS (yoy) }\end{array}$ & - & $43.41 \%$ & $24.82 \%$ & $8.35 \%$ & $7.06 \%$ & $16.40 \%$ \\
\hline
\end{tabular}

Pada Tabel I menyatakan market share (pangsa pasar) perbankan syariah di Indonesia telah mencapai target 5\% (pada kolom 2016) sebagaimana yang telah dicanangkan pasca disahkannya Undang-Undang No.2I tahun 2008 tentang Perbankan Syariah, yakni pencapaiannya pada akhir tahun 2016 yaitu 5.12\%. Ali Sakti dalam wawancara yang dilampirkan pada website go muslim mengatakan tak bisa dipungkiri bahwa keberhasilan perbankan syariah nasional dalam mencapai pangsa pasar 5.12 persen tidak terlepas dari keberhasilan Bank Pembangunan Daerah (BPD) Aceh yang melakukan konversi secara menyeluruh pada September 2016. Pertumbuhan market share perbankan syariah merupakan cerminan dari upaya pencapaian fungsi utama bank syariah, yakni menghimpun dana dari pihak ketiga (shahibul maal) dan menyalurkannya kembali melalui pembiyaan kepada mudharib.

Setiap perusahaan khususnya perbankan syariah selalu berusaha untuk tetap berkembang dan mampu bersaing, dalam rangka inilah maka setiap perbankan syariah selalu menetapkan strategi dan cara pelaksanaan kegiatan pemasarannya. Kegiatan pemasaran yang dilakukan, diarahkan untuk mencapai sasaran perusahaan yang dapat 
berupa tingkat laba yang diperoleh perusahaan dalam jangka panjang dan share pasar tertentu serta total unit dan volume penjualan tertentu dalam suatu jangka tertentu (Assauri, 2004).

Tabel 2. Perkembangan Jumlah Bank dan Jaringan Kantor Perbankan Syariah

\begin{tabular}{|c|c|c|c|c|c|c|}
\hline \multirow[t]{2}{*}{ Indikator } & \multicolumn{6}{|c|}{ Tahun } \\
\hline & $\begin{array}{c}201 \\
I\end{array}$ & $\begin{array}{c}201 \\
2\end{array}$ & 2013 & $\begin{array}{c}201 \\
4\end{array}$ & $\begin{array}{c}201 \\
5\end{array}$ & $\begin{array}{c}201 \\
6\end{array}$ \\
\hline \multicolumn{7}{|l|}{ Bank Umum Syariah (BUS) } \\
\hline I. Jumlah bank & II & II & II & 12 & 12 & 13 \\
\hline 2. Jumlah kantor & $|40|$ & 1745 & 1998 & 2163 & 1990 & 1869 \\
\hline \multicolumn{7}{|l|}{ Unit Usaha Syariah (UUS) } \\
\hline $\begin{array}{l}\text { I. Jumlah bank umum } \\
\text { konvensional yang memiliki }\end{array}$ & 24 & 24 & 23 & 22 & 22 & 21 \\
\hline $\begin{array}{l}\text { UUS } \\
\text { 2. Jumlah kantor }\end{array}$ & 336 & 517 & 590 & 320 & 311 & 332 \\
\hline \multicolumn{7}{|l|}{$\begin{array}{l}\text { Bank Pembiayaan Rakyat } \\
\text { Syariah (BPRS) }\end{array}$} \\
\hline I. Jumlah bank & 155 & 158 & 163 & 163 & 163 & 166 \\
\hline 2. Jumlah kantor & 364 & 401 & 402 & 439 & 446 & 453 \\
\hline
\end{tabular}

Sumber: Otoritas Jasa Keuangan - SPS Desember 2016 (data diolah)

Pada Tabel 2 dapat dilihat bahwa perbankan syariah di Indonesia berkembang sangat pesat meliputi jumlah bank dan jumlah kantor Bank Umum Syariah (BUS), Unit Usaha Syariah (UUS) dan Bank Pembiayaan Rakyat Syariah (BPRS) dari tahun 20II sampai bulan Desember tahun 2016 lalu, dimana terlihat bahwa jaringan kantor BPRS belum sebanyak BUS dan UUS, maka dapat dikatakan bahwa Bank Pembiayaan Rakyat Syariah merupakan salah satu bentuk lembaga ekonomi yang dapat menjadi mediator kebutuhan dana masyarakat.

Berdirinya BPRS dilatarbelakangi oleh kondisi ekonomi Indonesia yang tengah mengalami restrukrisasi ekonomi, restrukrisasi perekonomian di Indonesia itu terwujud dalam berbagai kebijakan baik di bidang keuangan, moneter termasuk dalam bidang perbankan (Hamidi, 2003). Selain itu, berdirinya BPRS dilatarbelakangi pula oleh adanya peluang bagi pengembangan bank Islam dalam Undang-Undang Perbankan yang membolehkan menggunakan prinsip bagi hasil. Sebagai Lembaga Keuangan Syariah, BPRS memiliki potensi besar untuk menjadi pilihan utama dan pertama bagi nasabah dalam pilihan transaksinya. Namun, BPRS pun harus menghadapi 
persaingan yang besar di industri perbankan, tidak hanya dengan sesama BPR, terutama dengan Bank yang memiliki modal besar seperti Bank Umum ataupun Bank Pembangunan Daerah.

Untuk meningkatkan pertumbuhan dan kinerja, perbankan syariah harus meningkatkan kemampuannya di pasar retail. Mereka harus menghasilkan inisiatifinisiatif untuk meningkatkan kemampuan retail sesuai potensi perbankan syariah di Indonesia, yakni meningkatkan penawaran produk sesuai kebutuhan segmen pasar yang dibidik, mereposisi kantor cabang sebagai pusat layanan dengan memisahkan fungsi back-office dan fungsi telemarketing dari cabang, memperkuat kapabilitas budaya pemasaran di seluruh lini, menjalin kerjasama dengan pihak ketiga untuk memperkuat layanan bancassurance, serta meningkatkan kemampuan manajemen aset dan manajemen risiko.

Salah satu strategi yang digunakan bank yaitu melalui promosi. Promosi merupakan salah satu bagian dari kegiatan pemasaran. Pemasaran merupakan suatu proses sosial dan manajerial yang membuat individu dan kelompok memperoleh apa yang mereka butuhkan dan inginkan lewat penciptaan dan pertukaran timbal balik produk dan nilai orang lain (Kotler dan Armstrong, 200I). Promosi adalah salah satu kegiatan yang dapat digunakan untuk dapat memperkenalkan perusahaan, produk dan jasa pada perbankan syariah, khususnya Bank Pembiayaan Rakyat Syariah kepada masyarakat luas. Dengan promosi, masyarakat dapat mengetahui dan memiliki minat untuk membeli manfaat dari produk yang ditawarkan oleh bank, karena promosi merupakan kegiatan yang ditujukan untuk mempengaruhi konsumen agar mereka mengenal produk atau jasa yang ditawarkan oleh suatu perusahaan kepada masyarakat.

Tingginya tingkat persaingan usaha dalam bisnis perbankan khususnya perbankan syariah menuntut pihak manajemen perusahaan untuk memiliki strategi promosi produk perbankannya dan merancang biaya promosi sebaik mungkin. Hal itu menyebabkan semua bank berlomba-lomba membuat strategi untuk memenangkan persaingan tersebut. Konsep pemasaran menegaskan bahwa kunci untuk mencapai tujuan organisasi yang ditetapkan adalah perusahaan tersebut harus menjadi lebih efektif dibandingkan para pesaing dalam menciptakan, 
menyerahkan, dan mengkomunikasikan nilai pelanggan kepada pasar sasaran yang telah terpilih (Al Arif, 20I0).

Menurut Al Arif (20I2), promosi yang dilakukan oleh dunia perbankan syariah masih sangat kurang sehingga masih banyak masyarakat yang tidak mengerti cara mengakses layanan perbankan syariah.. Aspek pendanaan memang menjadi kendala utama dalam melakukan promosi di bank syariah. Minimnya anggaran promosi yang dimiliki menyebabkan kurang gencarnya promosi yang dilakukan oleh bank syariah. Adapun anggaran promosi di bank konvensional relatif lebih besar dibandingkan dengan di bank syariah. Akhirnya, gaung perbankan syariah masih kalah dibandingkan dengan perbankan konvensional.

Tanpa promosi yang memadai, kemudahan masyarakat untuk mengakses layanan perbankan syariah tidak akan optimal. Hal ini menggambarkan sebuah tuntutan dan tantangan bagi setiap perusahaan perbankan khususnya Bank Pembiayaan Rakyat Syariah untuk merancang segi promosi produknya secara tepat dalam rangka mengembangkan serta mengenalkan berbagai produknya kepada seluruh lapisan masyarakat luas dan mampu meningkatkan dana pihak ketiga bank. Karena dengan jumlah penghimpunan dana dan jumlah pembiayaan yang disalurkan dapat mencerminkan market share perbankan syariah. Maka, setiap bank syariah memiliki dana khusus untuk kegiatan promosi bahkan dalam jumlah yang tidak sedikit. Pada Tabel 3 menggambarkan besaran biaya promosi yang dicanangkan serta komponen jumlah dana pihak ketiga yang diperoleh perbankan syariah di Indonesia.

Tabel 3. Biaya Promosi dan Komposisi Dana Pihak Ketiga

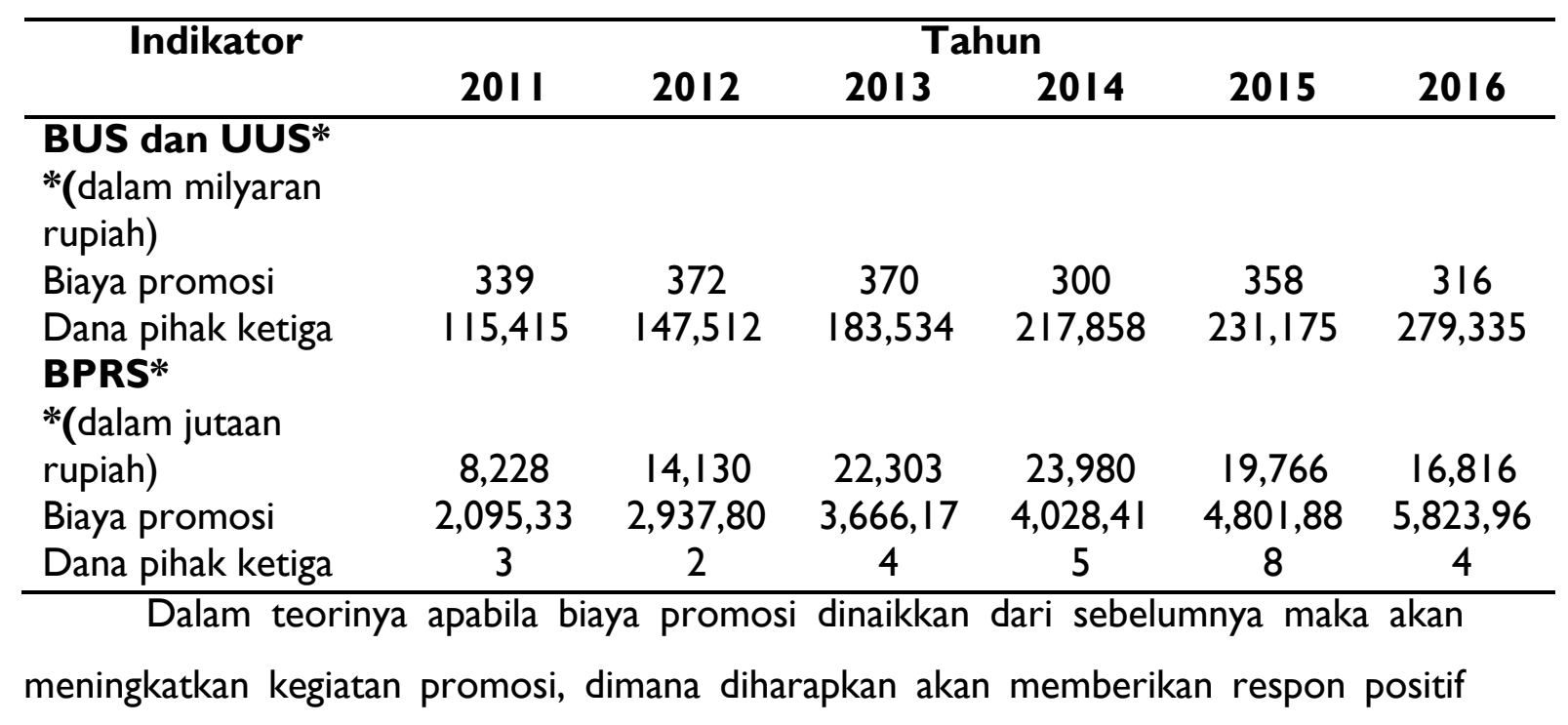


terhadap penjualan akan produk simpanan bank syariah. Bila penjualan produk simpanan (dana pihak ketiga) meningkat, dengan demikian diharapkan pula dapat meningkatkan pertumbuhan market share perbankan syariah.

\section{KAJIAN KEPUSTAKAAN}

Dana pihak ketiga (DPK) adalah dana yang diperoleh dari masyarakat berupa tabungan, giro dan deposito. Menurut Peraturan Bank Indonesia No.10/I9/PBI/2008 menjelaskan, "dana pihak ketiga, untuk selanjutnya disebut DPK adalah kewajiban bank kepada penduduk dalam bentuk rupiah dan valuta asing”. Perkembangan perbankan syariah dapat dilihat dari nilai pertumbuhan indikator-indikatornya. Menurut Kristin (20I5), beberapa indikator perbankan syariah, yaitu asset, dana pihak ketiga (DPK) dan kredit. Umumnya dana yang dihimpun oleh perbankan dari masyarakat akan digunakan untuk pendanaan aktifitas sektor riil melalui penyaluran kredit. Sama halnya dengan produk pada perbankan konvensional, produk perbankan syariah di bidang penghimpunan dana ini disebut sebagai simpanan, yaitu dana yang diperjanjikan penyimpanan dana dalam bentuk giro, deposito, sertifikat deposito, tabungan, dan atau bentuk lainnya yang dipersamakan dengan itu (Mardani: 2015). Produk-produk perbankan syariah yang termasuk ke dalam produk penghimpunan dana (funding) adalah giro wadiah, tabungan wadiah, tabungan mudharabah dan deposito mudharabah. Sedangkan dalam objek penelitian ini yaitu Bank Pembiayaan Rakyat Syariah (BPRS), yang termasuk ke dalam produk penghimpunan dana (funding) adalah hanya meliputi tabungan wadiah, tabungan mudharabah dan deposito mudharabah.

Tabel 4. Perkembangan Dana Pihak Ketiga BPRS (dalam jutaan rupiah)

\begin{tabular}{ccccc}
\hline & Maret & Juni & Sep & Des \\
\hline $\mathbf{2 0 0 8}$ & 772220 & 865319 & 896909 & 975815 \\
$\mathbf{2 0 0 9}$ & 1034228 & 1082786 & 1158034 & 1250603 \\
$\mathbf{2 0 1 0}$ & 1309987 & 1385733 & 1457768 & 1603778 \\
$\mathbf{2 0 1 1}$ & 1672303 & 1785628 & 1902369 & 2095333 \\
$\mathbf{2 0 1 2}$ & 2318437 & 2480775 & 2686937 & 2937802 \\
$\mathbf{2 0 1 3}$ & 3132989 & 3209453 & 3411188 & 3666174 \\
$\mathbf{2 0 1 4}$ & 3765463 & 3598842 & 3752963 & 4028415 \\
$\mathbf{2 0 1 5}$ & 4152997 & 4099039 & 4380037 & 4801888 \\
$\mathbf{2 0 1 6}$ & 4965547 & 4997238 & 5435445 & 5823964 \\
\hline
\end{tabular}


Produk sudah diciptakan, harga juga sudah ditetapkan, dan tempat (lokasi dan layout sudah dijelaskan), artinya produk sudah benar-benar siap untuk dijual. Agar produk tersebut laku dijual ke masyarakat atau nasabah, maka masyarakat perlu tahu kehadiran produk tersebut, berikut manfaat, harga, dimana dapat diperoleh dan kelebihan produk dibandingkan produk pesaing. Cara untuk memberitahukan kepada masyarakat adalah melalui sarana promosi. Artinya, keputusan terakhir bank harus mempromosikan produk tersebut seluas mungkin kepada nasabah. Instrumen dasar yang digunakan untuk mencapai tujuan komunikasi perusahaan disebut dengan bauran promosi atau promotional mix. Secara traditional, bauran promosi mencakup empat elemen, yaitu iklan (advertising), promosi penjualan (sales promotion), publikasi/humas, dan penjualan pribadi (personal selling) (Morissan, 2010).

Promosi adalah semua kegiatan yang dilakukan perusahaan untuk mengkomunikasikan dan mempromosikan produknya kepada pasar sasaran. Suatu perusahaan melakukan kegiatan promosi yang lancar agar produk yang dijual dikenali oleh masyarakat dan pada akhirnya berminat untuk membelinya. Promosi merupakan kegiatan marketing mix yang terakhir. Dalam kegiatan ini setiap bank berusaha untuk mempromosikan seluruh produk dan jasa yang dimilikinya baik langsung maupun tidak langsung (Kasmir, 20I4).

Secara garis besar promosi ditunjukkan untuk menginformasikan keberadaan dan keunggulan serta produk kepada para konsumen. Namun demikian tujuan dilakukannya suatu kegiatan promosi tidak saja sebagai upaya menginformasikan suatu produk tetapi juga sekaligus mengemukakan keunggulan produk dan mempengaruhi konsumen untuk melakukan tindakan pembelian. Hal ini diperlukan agar konsumen tahu dan menyadari bahwa suatu pemuas kebutuhannya dengan segala keunggulannya telah tersedia di pasar. Tujuan promosi adalah menginformasikan, memperngaruhi dan membujuk, serta mengingatkan pelanggan sasaran tentang perusahaan dan bauran pemasaran.

Biaya merupakan komponen penting yang juga mendapat perhatian. Kelangsungan hidup suatu perusahaan terkadang ditentukan oleh bagaimana perusahaan mengelola biaya-biaya yang ada. Dalam Kamus Besar Bahasa Indonesia (KBBI, 2005), biaya promosi adalah biaya untuk pendirian atau pengembangan perusahaan atau aktivitas baru; biaya yang dikeluarkan untuk usaha meningkatkan penjualan. Dalam arti 
luas biaya adalah pengorbanan sumber ekonomi, yang diukur dalam satuan uang, yang telah terjadi atau yang kemungkinan akan terjadi untuk tujuan tertentu (Mulyadi, 1990).

Menurut Septrianti (20I4), untuk melaksanakan kegiatan promosi perusahaan harus mengeluarkan biaya yang cukup tinggi dan hal ini membutuhkan perencanaan yang cukup matang serta efektif untuk mengetahui seberapa besar biaya promosi yang dikeluarkan oleh perusahaan. Anggaran merupakan sejumlah uang yang dihabiskan dalam periode tertentu untuk melaksanakan suatu program. Tidak ada satu perusahaan pun yang memiliki anggaran yang tidak terbatas, sehingga proses penyusunan anggaran atau biaya promosi menjadi hal penting dalam sebuah proses perencanaan kegiatan promosi. Biaya promosi pada bank syariah merupakan hal yang paling penting untuk dilakukan karena promosi merupakan kegiatan terpenting yang berperan aktif dalam memperkenalkan, memberitahukan dan mengingatkan kembali manfaat suatu produk yang dipromosikan tersebut. Karena dari banyaknya promosi yang dilakukan pada perbankan syariah tidak menyangkal bahwa semakin banyak nasabah yang akan menabung dan mempercayakan untuk menyimpan dana yang dimilikinya kepada bank syariah. Berikut tabel perkembangan biaya promosi Bank Pembiayaan Rakyat Syariah.

Tabel 5. Perkembangan Biaya Promosi BPRS (dalam jutaan rupiah)

\begin{tabular}{|c|c|c|c|c|c|c|c|c|c|}
\hline & 2008 & 2009 & 2010 & $201 \mathrm{I}$ & 2012 & 2013 & 2014 & 2015 & 2016 \\
\hline Mar & 737 & 1,006 & 949 & 1,516 & 2,227 & 4,994 & 6,828 & 4,283 & 4,101 \\
\hline Juni & $1,4 \mid 4$ & 2,024 & 2,353 & 3,132 & 5,624 & 9,664 & 13,333 & 8,767 & 9,767 \\
\hline Sep & 2,453 & 3,273 & 4,224 & 5,446 & 9,933 & 15,620 & 18,899 & 14,555 & 11,700 \\
\hline Des & 4,178 & 4,901 & 6,433 & 8,228 & 14,130 & 22,303 & 23,980 & 19,766 & 16,816 \\
\hline
\end{tabular}

oleh BPRS, terlihat bahwa terdapat naik turunnya besaran biaya promosi dari tahun ke tahun, namun terjadi pula penurunan besaran biaya promosi pada periode triwulan I sampai dengan periode triwulan IV tahun 2015 dan 2016. Dengan persentasi penurunan besaran biaya promosi pada tahun 20I5-2016 yakni triwulan I penurunannya sebesar 4\%, triwulan II sebesar II\%, triwulan III sebesar 20\% dan triwulan IV sebesar I5\%. 


\section{METODE}

Ruang lingkup penelitian pada penelitian ini ialah menggunakan metode penelitian kuantitatif yang menggunakan data runtun waktu (time series). Penelitian kuantitatif merupakan metode untuk menguji teori-teori tertentu dengan cara meneliti hubungan antarvariabel (Juliansyah, 20I2). Metode uji analisis yang digunakan yaitu uji autokorelasi, uji stasioneritas data, uji kointegrasi, uji regresi AutoRegressive Distributed Lag (ARDL) dan uji hipotesis.

Dalam penelitian ini menganalisis pengaruh biaya promosi terhadap penghimpunan dana pihak ketiga BPRS. Objek penelitian ini diambil dari laporan statistik perbankan syariah yaitu laporan keuangan bagian BPRS triwulan I s.d IV pada periode 2008-2016. Variabel yang digunakan diantaranya biaya promosi sebagai variabel bebas dan dan pihak ketiga sebagai variabel terikat. Bentuk persamaan model regresi ARDL dalam penelitian ini adalah sebagai berikut:

$$
\Delta Y_{t}=\alpha+\rho Y_{t-1}+\theta X_{t}+\omega_{1} \Delta X_{t-1}+\omega_{q} \Delta X_{t-q}+e_{t}
$$

Keterangan:

Yt : jumlah dana pihak ketiga BPRS periode sekarang

Yt-I : jumlah dana pihak ketiga BPRS periode sebelumnya

$\mathrm{P} \quad$ : fungsi sederhana dari $\phi \mid+. .+\phi P$

$\theta, \omega \mathrm{l}, . ., \omega q$ : ekuivalen dengan $\beta 0, . ., \beta q$

$X_{t} \quad$ : besaran biaya promosi BPRS periode sekarang

$\mathrm{X}_{t-I}, \mathrm{Xt-q}$ : besaran biaya promosi BPRS periode sebelumnya

Sebelum dilakukannya uji regresi ARDL akan dilakukan uji autokorelasi, uji stasioneritas data, uji kointegrasi dan penentuan lag optimum. Menurut Widarjono (20I6), selain uji $h$ yang diperkenalkan oleh Durbin, kita juga bisa mendeteksi ada tidaknya autokorelasi dalam model autoregresif dengan menggunakan uji yang dikembangkan oleh Breusch-Godfrey yang dikenal dengan Uji LM atau Langrange Multiple. Uji Langrange Multiple (LM test) dapat digunakan untuk menguji adanya masalah autokorelasi tidak hanya pada derajat pertama (first order) tetapi juga digunakan pada berbagai tingkat derajat autokorelasi (Suliyanto, 20I I).

Uji selanjutnya yang penting dilakukan sebelum melakukan uji ARDL adalah uji stasioneritas data. Data time series seringkali tidak stasioner sehingga menyebabkan hasil regresi yang meragukan atau sering disebut regresi lancung (superious regression). 
Regresi lancung adalah situasi dimana hasil regresi menunjukkan koefisien regresi yang signifikan secara statistik dan nilai koefisien determinasi yang tinggi namun hubungan antar variabel di dalam model tidak saling berhubungan. Data yang tidak stasioner seringkali menunjukkan hubungan ketidakseimbangan dalam jangka pendek, tetapi ada kecenderungan terjadinya hubungan keseimbangan dalam jangka panjang (Widarjono, 2016). Agar regresi yang dihasilkan tidak rancu (meragukan) kita perlu merubah data tidak stasioner menjadi data stasioner.

Metode uji stasionaritas dilakukan dengan uji akar-akar unit (unit root test). Uji akar unit yang sekarang terkenal adalah uji dari Dickey Fuller (DF) dan Phillips Perron (PP), dan dalam peneltian ini akan digunakan uji akar unit dengan uji Philips Perron (PP). Prosedur untuk menentukan apakah data stasioner atau tidak dengan cara membandingkan antara nilai statistik PP dengan nilai kritisnya yaitu distribusi statistik Mackinnon. Jika nilai absolut statistik PP lebih besar dari nilai kritisnya, maka data yang diamati menunjukkan stasioner dan jika sebaliknya nilai absolut statistik PP lebih kecil dari nilai kritisnya maka data tidak stasioner (Widarjono, 2016).

Secara umum bisa dikatakan bahwa jika data time series tidak stasioner pada tingkat level tetapi menjadi stasioner pada tingkat diferensi pertama atau diferensi $\left(I^{\text {st }}\right.$ difference) yang sama, maka data tersebut terkointegrasi (mempunyai hubungan dalam jangka panjang). Jadi, uji kointegrasi hanya bisa dilakukan ketika data yang digunakan dalam penentuan berintegrasi pada derajat yang sama. Alternatif uji kointegrasi yang sekarang banyak digunakan adalah uji kointegrasi yang dikembangkan oleh Johansen.

Pada penelitian ini uji kointegrasi akan dilakukan dengan menggunakan uji kointegrasi Johansen. Uji yang dikembangkan Johansen dapat digunakan untuk menentukan kointegrasi sejumlah variabel atau vector (Widarjono: 2016). Untuk menjelaskan ada tidaknya kointegrasi dengan melihat nilai trace statistic dan nilai maximum eigenvalue statistic dengan nilai kritis pada tingkat keyakinan 5\%. Jika nilai hitung trace statistic dan maximum eigenvalue statistic lebih besar dari nilai kritis maka kita menerima adanya kointegrasi sejumlah variabel dan sebaliknya jika nilai hitung trace statistic dan maximum eigenvalue statistic lebih kecil dari nilai kritisnya maka tidak ada kointegrasi. 
Permasalahan yang sering muncul dari model ARDL adalah menentukan pada lag ke-berapa variabel tersebut akan menghasilkan hasil estimasi yang baik. Penentuan panjang lag penting karena lag yang terlalu panjang akan mengurangi banyaknya degree of freedom, sedangkan lag yang terlalu pendek akan mengarah pada kesalahan spesifikasi (Gujarati: 2004). Untuk memilih lag optimum pada model ARDL beberapa peneliti menggunakan Schwarz Criterion (SC) dan Akaike Information Criteria (AIC) terkecil melalui uji VAR pada aplikasi eviews. Langkah penentuan lag optimum ini berguna untuk memilih lag ke-berapakah variabel -variabel dari model regresi ARDL menghasilkan estimasi yang baik.

Uji t pada dasarnya menunjukan seberapa jauh pengaruh variabel bebas secara individual dalam menerangkan varians variabel $t$. Membandingkan nilai statistik $t$ hitung dengan titik kritis menurut tabel apabila nilai hasil $t_{\text {hitung }}$ lebih tinggi dibanding nilai $t_{\text {tabel}}$. Apabila $\mathrm{t}_{\text {hitung }}>\mathrm{t}$ tabel maka $\mathrm{H}_{0}$ ditolak dan $\mathrm{H}_{\mathrm{a}}$ diterima, artinya variabel independen secara parsial mempunyai pengaruh yang signifikan terhadap variabel dependen dan begitu pula sebaliknya.

Uji $\mathrm{F}$ pada dasarnya kriteria pengambilan keputusan dilakukan dengan tingkat signifikansi $5 \%$. $\mathrm{H}_{\mathrm{a}}$ akan diterima jika tingkat signifikansi < 5\% (kurang dari 0,05) dan $\mathrm{H}_{\mathrm{a}}$ ditolak apabila tingkat signifikansi $>5 \%$. Maksudnya jika $F_{\text {hitung }}>F_{\text {tabel }}$ maka $H_{0}$ ditolak dan $\mathrm{H}_{\mathrm{a}}$ diterima, artinya variabel independen secara simultan mempunyai pengaruh yang signifikan terhadap variabel dependen dan begitu pula sebaliknya.

\section{HASIL ANALISIS DAN PEMBAHASAN}

Berdasarkan hasil pengolahan data dengan eviews 9, hasil uji autokorelasi dapat dilihat seperti pada Tabel 6. Hasil uji autokorelasi tersebut menunjukkan nilai probabilitas chi-square $=0.2457$ atau $24.57 \%$, dengan $\alpha=24.57 \%$ tersebut maka secara statistik tidak signifikan sehingga model tidak mengandung unsur autokorelasi atau dapat disimpulkan error pada model tidak mengalami masalah serial korelasi.

Tabel 6. Hasil Uji Autokorelasi

\begin{tabular}{lrll}
\hline \multicolumn{4}{l}{ Breusch-Godfrey Serial Correlation LM Test: } \\
\hline F-statistic & 0.949518 & Prob. F(8,I9) & 0.4976 \\
Obs*R-squared & 9.098282 & Prob. Chi-Square(8) & 0.2457 \\
\hline
\end{tabular}


Uji selanjutnya yaitu uji stasioneritas data, suatu data dapat dikatakan stasioner apabila seluruh data variabel $X$ dan $Y$ pada penelitian sama-sama telah stasioner atau telah lulus uji stasioner data. Maka, untuk mendapatakan data yang stasioner dilakukan pengujian selanjutnya pada tingkat differensi satu ( ${ }^{\text {st }}$ difference). Hasil pengujian pada tingkat $I^{\text {st }}$ difference telah ditampilkan pada Tabel 7 dengan hasil uji variabel DPK dan biaya promosi memperoleh nilai $t$ statistk sebesar DPK -4.74 dan biaya promosi - I3.43 sudah lebih besar daripada nilai $t$ pada tabel MacKinnon pada tingkat kepercayaan 1\%, 5\%, maupun 10\%, sehingga dapat disimpulkan bahwa variabel DPK maupun biaya promosi telah stasioner pada tingkat differensi satu ( ${ }^{\text {st }}$ difference). Serta nilai probabilitas yang diperoleh sebesar 0.0029 (DPK) dan 0.0000 (Biaya Promosi) sudah lebih kecil dari nilai kritik $0.05(0.0029<0.05$ dan $0.0000<0.05)$. Dengan demikian data telah stasioner pada diferensiasi tahap pertama ( ${ }^{\text {st }}$ difference) dan hipotesis null dapat ditolak.

Tabel 7. Hasil Uji Staisoneritas

\begin{tabular}{|c|c|c|c|c|c|c|c|}
\hline \multirow[t]{2}{*}{ No. } & \multirow[t]{2}{*}{ Variabel } & \multicolumn{6}{|c|}{ PP } \\
\hline & & \multicolumn{2}{|c|}{ At Level* } & Prob.* & \multicolumn{2}{|c|}{ I $^{\text {st }}$ Difference* } & Prob.* \\
\hline \multirow[t]{4}{*}{ I. } & DPK & & -0.801247 & 0.9559 & & -4.748383 & $0.0029 * *$ \\
\hline & & $1 \%$ & -4.243644 & & $1 \%$ & -4.252879 & \\
\hline & & $5 \%$ & -3.544284 & & $5 \%$ & -3.548490 & \\
\hline & & $10 \%$ & -3.204699 & & $10 \%$ & -3.207094 & \\
\hline \multirow[t]{4}{*}{2.} & Biaya & & -5.238805 & 0.0008 & & -13.43528 & $0.0000 * *$ \\
\hline & Promosi & $1 \%$ & -4.243644 & & $1 \%$ & -4.252879 & \\
\hline & & $5 \%$ & -3.544284 & & $5 \%$ & -3.548490 & \\
\hline & & $10 \%$ & -3.204699 & & $10 \%$ & -3.207094 & \\
\hline
\end{tabular}

**Keterangan: Tingkat signifikansi $<0.05$

Sumber: Hasil penelitian diolah menggunakan Eviews 9

Setelah diperoleh hasil uji stasioner data di atas bahwa data pada penelitian telah stasioner pada tingkat diferensi pertama $\left(\mathrm{I}^{\text {st }}\right.$ difference), maka uji kointegrasi dapat dilakukan. Karena dalam estimasi ARDL, uji kointegrasi Johansen hanya dapat dilakukan apabila keseluruhan variabel penelitian telah stasioner pada tingkat $I^{\text {st }}$ difference. Hasil pengujiannya dapat ditunjukkan pada Tabel 8. 
Tabel 8. Hasil Uji Kointegrasi Johansen

\begin{tabular}{|c|c|c|c|c|}
\hline $\begin{array}{l}\text { Hypothesized } \\
\text { No. of CE(s) }\end{array}$ & Eigenvalue & $\begin{array}{c}\text { Trace } \\
\text { Statistic }\end{array}$ & $\begin{array}{c}0.05 \\
\text { Critical Value }\end{array}$ & Prob.** \\
\hline None* & 0.655379 & 40.10427 & $|5.4947|$ & 0.0000 \\
\hline At most I* & 0.107945 & 3.883753 & 3.841466 & 0.0487 \\
\hline \multicolumn{5}{|c|}{ Trace test indicates 2 cointegrating eqn(s) at the 0.05 level } \\
\hline \multicolumn{5}{|c|}{$\begin{array}{l}\text { *denotes rejection of the hypothesis at the } 0.05 \text { level } \\
\text { **MacKinnon-Haug-Michelis (1999) p-values }\end{array}$} \\
\hline \multirow{2}{*}{\multicolumn{5}{|c|}{ Unrestricted Cointegration Rank Test (Maximum Eigenvalue) }} \\
\hline & & Max-Eigen & 0.05 & \\
\hline No. of CE(s & Eigenvalue & Statistic & $\begin{array}{l}\text { Critical } \\
\text { Value }\end{array}$ & Prob.** \\
\hline None* & 0.655379 & 36.22052 & 14.26460 & 0.0000 \\
\hline At most I* & 0.107945 & 3.883753 & 3.841466 & 0.0487 \\
\hline
\end{tabular}

Max-eigenvalue test indicates 2 cointegrating eqn(s) at the 0.05 level

*denotes rejection of the hypothesis at the 0.05 level

**MacKinnon-Haug-Michelis (1999) p-values

Sumber: Hasil Penelitian Diolah Menggunakan Eviews 9

Pada hasil tersebut bandingkan nilai trace statistic dan nilai maximum eigenvalue statistic dengan nilai kritis pada tingkat keyakinan 5\%. Ternyata pada baris pertama dan kedua nilai trace statistic dan nilai maximum eigenvalue statistic -nya lebih besar dibanding nilai kritis pada tingkat keyakinan 5\%, sehingga dapat disimpulkan bahwa terdapat dua persamaan kointegrasi yang terbentuk. Terdapat cara yang lain untuk mengetahui ada tidaknya kointegrasi, yaitu dengan membaca baris terakhir pada Tabel 8, yaitu tulisan: Trace test indicates 2 cointegrating eqn (s) at 0.05 level dan Max-eigenvalue test indicates 2 cointegrating eqn(s) at the 0.05 level, yang menyatakan bahwa terdapat dua persamaan kointegrasi pada tingkat keyakinan 5\%. Langkah selanjutnya sebelum dilakukan uji ARDL yaitu pentingnya untuk melakukan uji penentuan lag optimum, hal ini berguna untuk memilih lag ke-berapakah variabel-variabel dari model regresi ARDL menghasilkan estimasi yang baik.

Berdasarkan Tabel 9, melihat panjang lag yang optimum pada tabel adalah dengan melihat tanda $(*)$ terbanyak, yaitu yang terdapat pada lag ke-7, maka dapat disimpulkan bahwa variabel lag ke-7 tersebut yang akan menghasilkan estimasi terbaik dalam melakukan uji ARDL. Maka, dalam penelitian ini lag ke-7 dapat ditentukan dari dimulainya data penelitian yakni, data biaya promosi dan dana pihak ketiga triwulan I tahun 2008. 
Tabel 9. Lag Optimum

\begin{tabular}{ccccccc}
\hline Lag & LogL & LR & FPE & AIC & SC & HQ \\
\hline 0 & -687.4849 & NA & $5.20 \mathrm{e}+19$ & 51.07296 & 51.16894 & 51.10150 \\
1 & -623.1528 & 114.3683 & $5.97 \mathrm{e}+17$ & 46.60391 & 46.89187 & 46.68954 \\
2 & -599.1644 & 39.09208 & $1.37 \mathrm{e}+17$ & 45.12329 & 45.60323 & 45.26600 \\
3 & -589.6871 & 14.04055 & $9.25 \mathrm{e}+16$ & 44.71756 & 45.38948 & 44.91736 \\
4 & -566.9181 & 30.35867 & $2.37 \mathrm{e}+16$ & 43.32726 & 44.19116 & 43.58414 \\
5 & -562.2902 & 5.484859 & $2.37 \mathrm{e}+16$ & 43.28076 & 44.33662 & 43.59472 \\
6 & -555.6191 & 6.918227 & $2.09 \mathrm{e}+16$ & 43.08289 & 44.33074 & 43.45394 \\
7 & -542.0228 & $12.08561 *$ & $1.15 \mathrm{e}+16 *$ & $42.37206 *$ & $43.81188 *$ & $42.80019 *$ \\
8 & -539.0831 & 2.177520 & $1.46 \mathrm{e}+16$ & 42.45060 & 44.08240 & 42.93582 \\
9 & -534.6049 & 2.653761 & $1.79 \mathrm{e}+16$ & 42.41518 & 44.23895 & 42.95748 \\
\hline
\end{tabular}

*indicates lag order selected by the criterion

Sumber: Hasil Penelitian Diolah Menggunakan Eviews 9

Kemudian, setelah dilakukan pengujian VAR menghasilkan panjang lag optimum yang akan menghasilkan estimasi terbaik untuk uji ARDL adalah lag 7, maka dalam uji ARDL yang dilakukan akan menggunakan indikasi pada lag ke- 7. Hasil uji ARDL ditampilkan pada Tabel 10 dengan alat bantu program pengolahan data statistik Eviews 9, menjelaskan koefisien variabel DPK lag I (DPK triwulan I tahun 2009), variabel biaya promosi periode $t$ (biaya promosi triwulan 2 tahun 2009), variabel biaya promosi lag I (biaya promosi triwulan I tahun 2009), variabel biaya promosi lag 2 (biaya promosi triwulan 4 tahun 2008), variabel biaya promosi lag 3 (biaya promosi triwulan 3 tahun 2008), variabel biaya promosi lag 4 (biaya promosi triwulan 2 tahun 2008) dan variabel biaya promosi lag 5 (biaya promosi triwulan 3 tahun 2008).

Berdasarkan koefisien yang ditampilkan pada tabel, variabel DPK lag I atau DPK triwulan I tahun 2009 memiliki hubungan yang positif dan signifikan terhadap DPK periode $t$ atau (DPK triwulan 2 tahun 2009) dengan nilai koefisiennya sebesar I.094464, hal ini berarti saat DPK triwulan I tahun 2009 naik sebesar I\% maka akan menaikkan DPK triwulan 2 tahun 2009 sebesar I.094\%. Selanjutnya, biaya promosi lag I (biaya promosi triwulan I tahun 2009) dan biaya promosi lag 4 (biaya promosi triwulan 2 tahun 2008) juga memiliki pengaruh positif dan signifikan 
terhadap DPK periode $t$ (DPK triwulan 2 tahun 2009) dengan koefisien yang didapat yaitu biaya promosi lag I sebesar II.868I0 dan biaya promosi lag 4 sebesar 12.827I5, hal ini berarti saat biaya promosi triwulan I tahun 2009 naik I\% maka akan menaikkan DPK triwulan 2 tahun 2009 sebesar II.868\%, dan saat biaya promosi triwulan 2 tahun 2008 naik I\% maka akan menaikkan DPK periode triwulan 2 tahun 2009 sebesar $12.827 \%$.

Selanjutnya, biaya promosi lag 2 (biaya promosi triwulan 4 tahun 2008) dan lag 3 (biaya promosi triwulan 3 tahun 2008) terlihat memberikan pengaruh negatif signifikan terhadap DPK periode $t$ (DPK triwulan 2 tahun 2009), dengan koefisien biaya promosi lag 2 sebesar - 18.54424 dan lag 3 sebesar -7.8|4797. Hal ini berarti saat biaya promosi triwulan 4 tahun 2008 dan saat biaya promosi triwulan 3 tahun 2008 dinaikkan sebesar I\% maka dapat menyebabkan menurunnya DPK periode $t$ (DPK triwulan 2 tahun 2009) sebesar $18.5 \%$ dan $7.81 \%$. Sedangkan biaya promosi periode $t$ (biaya promosi triwulan 2 tahun 2009) dan biaya promosi lag 5 (biaya promosi triwulan I tahun 2008) terlihat memberikan pengaruh negatif tidak signifikan terhadap DPK periode $t$ (DPK triwulan 2 tahun 2009) dengan nilai koefisien yang didapat yaitu biaya promosi periode $t$ sebesar -7.998106 dengan nilai probabilitasnya sebesar 0.1148 dan pada biaya promosi lag 5 koefisiennya sebesar -9.655904 dengan nilai probabilitasnya 0.1031 .

Tabel I0. Hasil Uji ARDL

\begin{tabular}{crrrr}
\hline Variable & Coefficient & Std. Error & t-Statistic & Prob. \\
\hline DPK(-I) & 1.094464 & $0.01644 \mathrm{I}$ & 66.56782 & 0.0000 \\
BIAYA_PROMOSI & -7.998106 & $4.87956 \mathrm{I}$ & -1.639104 & 0.1148 \\
BIAYA_PROMOSI(-I) & $\mathrm{I} 1.86810$ & 4.799943 & 2.472550 & 0.0212 \\
BIAYA_PROMOSI(-2) & -18.54424 & $1.96496 \mathrm{I}$ & -9.437459 & 0.0000 \\
BIAYA_PROMOSI(-3) & -7.814797 & $1.89427 \mathrm{I}$ & -4.125490 & 0.0004 \\
BIAYA_PROMOSI(-4) & 12.82715 & 5.337947 & 2.403012 & 0.0247 \\
BIAYA_PROMOSI(-5) & -9.655904 & 5.688602 & -1.697412 & 0.1031 \\
C & 37790.53 & 23890.86 & 1.581798 & 0.1274
\end{tabular}

Sumber: Hasil Penelitian Diolah Menggunakan Eviews 9 
Berdasarkan hasil pengujian ARDL pada Tabel 10, maka persamaan yang didapat dari regresi ARDL dinyatakan sebagai berikut:

$\Delta$ DPK $\boldsymbol{t}: 37790.53+1.094464$ (DPK (-I)) -7.998106 (Biaya Promosi $t)+11.86810$ (Biaya Promosi (-I)) - 18.54424 (Biaya Promosi (-2)) - 7.814797 (Biaya Promosi (-3)) + 12.82715 (Biaya Promosi (-4)) - 9.655904 (Biaya Promosi (5)) $+e_{t}$

Interpretasi dari hasil berbagai pengujian dan analisis dalam regresi pada setiap model penelitian yang dilakukan adalah bahwa hasil uji ARDL yang didapat yakni menunjukkan variabel DPK periode $t$ pada penelitian ini yaitu DPK triwulan 2 tahun 2009 dipengaruhi secara positif dan signifikan oleh DPK triwulan I tahun 2009, kemudian biaya promosi triwulan I tahun 2009 dan biaya promosi periode triwulan 2 tahun 2008. Hal ini mengidentifikasikan bahwa efektifitas pengaruh yang diberikan oleh besaran biaya promosi terhadap perubahan Dana Pihak Ketiga (DPK) terjadi pada tiga sampai lima belas bulan sebelumnya (setiap perubahan Dana Pihak Ketiga periode $t$ akan dipengaruhi oleh besaran biaya promosi 15 bulan sebelumnya).

Kemudian, hasil uji simultan $F$ pada penelitian ini didapatkan, nilai $F_{\text {hitung }}$ (3482.96I) $>\mathrm{F}_{\text {tabel }}$ (3.23), maka $\mathrm{HO}$ ditolak artinya koefisien regresi signifikan, dan memberikan kesimpulan bahwa variabel independen biaya promosi secara simultan mempengaruhi variabel dependen DPK. Nilai adjusted $\mathrm{R}^{2}$ sebesar 0.99877 I yang berarti 99.87\% peningkatan DPK ditentukan oleh variabel independen biaya promosi dan $\quad 0.13 \% \quad(100 \%-99.87 \%)$ sisanya disebabkan oleh faktor lain di luar model penelitian.

Berdasarkan beberapa variabel lag yang diuji, secara parsial t hanya tiga variabel lag yang berpengaruh positif signifikan terhadap perubahan Dana Pihak Ketiga yaitu DPK lag ke satu atau DPK triwulan I tahun 2009, biaya promosi triwulan I tahun 2009 atau biaya promosi saat lag ke satu dan biaya promosi periode triwulan 2 tahun 2008 atau biaya promosi saat lag ke empat. Kemudian berdasarkan uji yang dilakukan secara simultan (uji F) menunjukkan bahwa seluruh lag dari variabel biaya promosi memiliki pengaruh signifikan secara simultan terhadap perubahan Dana Pihak Ketiga. 
Hal ini menandakan bahwa semakin tinggi anggaran biaya promosi yang dilakukan, maka BPRS akan mampu menghimpun dana pihak ketiga lebih besar. Karena dengan perencanaan biaya promosi dan kegiatan promosi yang dilakukan oleh BPRS akan memberikan pengetahuan secara luas kepada masyarakat terhadap berbagai produk yang ditawarkan. Hal ini sesuai dengan penelitian yang telah dilakukan oleh Fierman (2009) pada bank BNI syariah; Lestari (2009) pada bank Mega syariah dengan menganalisis efektifitas biaya promosi dan pengaruhnya terhadap dana pihak ketiga. Demikian pula dengan penelitian oleh Al Arif (2010) yang menganalisis efektifitas biaya promosi dan biaya diklat terhadap penghimpunan dana pihak ketiga bank syariah yang meliputi bank umum syariah (BUS) dan unit usaha syariah (UUS). Ketiga penelitian terdahulu tersebut telah menyatakan bahwa biaya promosi yang dikeluarkan bank syariah mempunyai pengaruh positif terhadap perubahan dana pihak ketiga serta dapat meningkatkan dana pihak ketiga secara signifikan.

\section{SIMPULAN}

Berdasarkan hasil pengolahan data, hasil analisis dan interpretasi data pada bab sebelumnya maka dapat ditarik kesimpulan sebagai berikut: (I) Berdasarkan hasil uji ARDL yang telah dilakukan, dapat disimpulkan bahwa DPK periode $t$ atau DPK triwulan 2 tahun 2009 dipengaruhi secara positif dan signifikan oleh DPK triwulan I tahun 2009, kemudian biaya promosi triwulan I tahun 2009 dan biaya promosi triwulan 2 tahun 2008. (2) Hasil analisis ARDL mengidentifikasikan bahwa efektifitas pengaruh yang diberikan oleh besaran biaya promosi terhadap perubahan Dana Pihak Ketiga terjadi pada tiga sampai lima belas bulan sebelumnya atau dapat dikatakan juga bahwa setiap perubahan Dana Pihak Ketiga periode $t$ akan dipengaruhi oleh DPK 3 bulan sebelumnya dan dipengaruhi pula oleh besaran biaya promosi 15 bulan sebelumnya. (3) Berdasarkan hasil uji simultan $F$ terhadap variabel penelitian menunjukkan bahwa seluruh lag dari variabel biaya promosi memiliki pengaruh signifikan secara simultan terhadap perubahan Dana Pihak Ketiga, dengan nilai adjusted $\mathrm{R}^{2}$ sebesar $0.99877 \mathrm{I}$ yang berarti variabilitas DPK yang dapat dijelaskan oleh variabel independen biaya promosi sebesar 
99.87\%, dengan kata lain $99.87 \%$ peningkatan DPK ditentukan oleh variabel independen biaya promosi dan 0.13\%(100\%-99.87\%) sisanya disebabkan oleh faktor lain di luar model penelitian.

\section{PUSTAKA ACUAN}

Al Arif, M. Nur Rianto. 2010. Dasar-Dasar Pemasaran Bank Syariah. Bandung: Alfabeta.

Al Arif, M. Nur Rianto. 2012. Lembaga Keuangan Syariah: Suatu Kajian Teoretis Praktis, Cet. I. Bandung: CV Pustaka Setia.

Assauri, Sofjan. 2004. Manajemen Pemasaran, Cet. Keempat. Jakarta: PT Grafindo Persada.

Gujarati, Damodar N. dan Dawn C. Porter. 2004. Dasar-Dasar Ekonometrika. Jakarta: Salemba Empat.

Hamidi, M. Lutfi. 2003. Jejak-Jejak Ekonomi Syariah. Jakarta: Senayan Abadi Publishing.

Hasanah, Nurul Asri. 20II. Korelasi Antara Biaya Promosi Dengan Tingkat Pendapatan Studi Kasus BSM Cabang Mayestik. Skripsi Tidak Dipublikasikan Jakarta: Uhamka.

Kasmir. 2005. Pemasaran Bank, Edisi Pertama, Cetakan ke-2. Jakarta: Kencana.

Kasmir. 2014. Manajemen Perbankan. Jakarta: Rajawali Pers.

Kotler, Philip dan Gary Armstrong. 200I. Prinsip-Prinsip Pemasaran. Jakarta: Erlangga.

Kristin Prasetyoningrum, Ari. 2015. Risiko Bank Syariah: Risiko Imbal Hasil, Risiko Imbal Hasil, Risiko Investasi, Return Tingkat Dana Pihak Ketiga dan BI Rate. Yogyakarta: Pustaka Belajar.

Mardani. 2015. Aspek Hukum Lembaga Keuangan Syariah di Indonesia. Jakarta: Prenadamedia Group.

Morissan. 2010. Periklanan: Komunikasi Pemasaran Terpadu. Jakarta: Kencana.

Mulyadi. 1990. Akuntansi Biaya. Yogyakarta: BPFE-Yogyakarta,.

Noor, Juliansyah. 2012. Metode Penelitian: Skripsi, Tesis, Disertasi, dan Karya Ilmiah, Edisi Pertama. Jakarta: Kencana. 
Septrianti, Rizal, dan Lanto. Pengaruh Biaya Promosi Terhadap Pendapatan Premi PT. Asuransi Umum Bumiputera Muda 1967 Cab. Gorontalo Periode 2005-20I4. Jurnal Manajemen Universitas Negeri Gorontalo.

Suliyanto. 20II. Ekonometrika Terapan: Teori \& Aplikasi dengan SPSS. Yogyakarta: ANDI.

Tim Penyusun Kamus Pusat Bahasa. 2005. Kamus Besar Bahasa Indonesia. Jakarta: Balai Pustaka.

Widarjono, Agus. 2016. Ekonometrika: Pengantar dan Aplikasinya Disertai Panduan Eviews. Yogyakarta: UPP STIM YKPN. 